JOURNAL OF SECURITY AND SUSTAINABILITY ISSUES

ISSN 2029-7017 print/ISSN 2029-7025 online

2019 June Volume 8 Number 4

http://doi.org/10.9770/jssi.2019.8.4(14)

\title{
Scopus
}

\section{JUSTIFICATION OF THE STRATEGY OF ECONOMIC SECURITY OF ORGANIZATION IN THE CONDITIONS OF INNOVATION DEVELOPMENT}

\author{
Yuri Tsenkov \\ University of National and World Economy, 1700 Sofia, Student Town, Bulgaria \\ E-mail: koaduep@gmail.com
}

Received 22 November 2018; accepted 13 March 2019; published 30 June 2019

\begin{abstract}
It was argued that the development of an effective strategy for the protection of the industrial organization and ensuring its proper implementation should be based on the methodological basis of the theory of security. The fundamental changes in the process of formation of a security strategy are determined by the fact that the process specified is objectively developing and gradually becoming more complicated. At the present stage, the security strategy is formalized into a certain organized system, which should include the existing structural subdivisions of the business entity and create conditions for the protection of the priority areas of its operations. The main objective of formation of a strategy for the protection of entrepreneurship is the early distinguishing and isolation of external and internal dangers and threats, overcoming existing imbalances in the process of formation of the innovative basis for further development, creation of a safe environment for the existence of a business entity and, ultimately, achieving the stated goals of a particular industrial organization. All this allows us to formulate an appropriate strategy for its economic security.
\end{abstract}

Keywords: economic security, security strategy, innovative development

Reference to this paper should be made as follows: Tsenkov, Y. 2019. justification of the strategy of economic security of organization in the conditions of innovation development, Journal of Security and Sustainability Issues 8(4): 715-725.

http://doi.org/10.9770/jssi.2019.8.4(14)

JEL Classifications: F52, O39

\section{Introduction}

The need to form a stable and promising real segment of the economy and provision of a favourable foundation for improvement of the well-being of the industrialized regions determines the key vectors of urgent tasks regarding the forms and methods for the full implementation of organizations' own strategic capabilities on a scientifically grounded platform.

The strategic management of the business entity as a basis for management activity has become widespread due to the need for an operational response to the transformation in the field of enterprise activities. These features led to an increase in the interest of scientists and manufacturers in quality new management, first of all, in relation to the problems of strategic analysis, alternative choices and development of an effective strategy. At the same time, it is almost unrealistic to predict the likely performance of an enterprise because it represents a branched open system and is subjected to a significant influence of a number of factors that are not part of the controlled zone, which in turn leads to a decrease in the viability of the outlined strategy. Therefore, the business entity's readiness for such changes, achieving stability, productivity, and adaptability necessary for the implementation of the chosen strategy is also a very important and difficult task of modern strategic management, as well as the formation of a strategy requires appropriate skills and abilities employees of an industrial organization, since any most successful strategy does not guarantee the desired results, or, in the case 
of unprofessional implementation of it, may lead to deterioration of the situation, whereas even an imperfect false strategy can yield successful results in case of the application of a highly professional approach.

The development of an effective system of the economic security strategy of an industrial enterprise and ensuring its proper existence must be based on the methodological basis of the theory of security. It is important to correctly outline the goal of the business entity's security, set of tasks for the successful implementation of a specific goal, key functions of the established industrial enterprise security system, that is, it is necessary to clearly define the scope of the operation of the specified system.

\section{Literature Survey}

Consequently, the fundamental changes in the process of formation of the economic security strategy are determined by the fact that this process is completely objectively evolving and gradually becoming more complicated (Havierniková, K.; Kordoš, M. (2019)). Not so long ago, the achievement of the economic security strategy consisted in the coexistence of disparate tasks and vectors, which, as a rule, were not closely interconnected, but in essence only formally functioned (Dueri, S., Guillotreau, P., Jiménez-Toribio , R., OliverRamos, R., Bopp, L., \& Maury, O. (2016), Von Gliszczynski, M., \& Leisering, L. (2016)). At the present stage, these tendencies are formalized in a certain organized system, which should include existing structural subdivisions of the subject of business and create conditions for the protection of priority areas of work and availability of resources (Tetiana, H., Karpenko, L., Fedoruk, O., Shevchenko, I., \& Drobyazko, S. (2018); Dobrovolskienè, N.; Tvaronavičienè, M.; Tamošiūnienè, R. (2017)).

The main goal of the outlined system of the economic security strategy of entrepreneurship is the early identification and isolation of external and internal dangers and threats, creation of a safe environment for the existence of the business entity and, eventually, the achievement of the stated goals of a certain industrial organization (Hilorme, T., Nazarenko Inna, Okulicz-Kozaryn, W., Getman, O. \& Drobyazko, S. (2018); Monni, S.; Palumbo, Tvaronavičienè, M. (2017); Tvaronavičienè, M. (2018); Ciobanu A., Androniceanu A. (2018)). The effectiveness and reliability of a system of economic security strategy of a business entity are determined primarily by material and moral damage, its presence or absence. The essence of such an indicator is primarily determined by the following criteria: prevention of disclosure of confidential data; prevention of illegal actions of the personnel of the enterprise, its visitors, counteragents; maintenance of the security of property and intellectual property of the subject of management; prevention of manifestations of force majeure events; prevention of unlawful violent actions against certain (specially assigned) workers of the enterprise; early warning of attempts to gain access to certain objects of an industrial organization (Drobyazko, S. (2018a), Drobyazko, S. (2018b)).

The formation of an economic security strategy involves the need to develop a specific action plan that can prepare the company to overcome the adverse impacts that will likely arise in the future in obtaining strategic benefits that can be achieved, taking into account the existing level of threats that can be predicted and quantified, in order to protect the business entity on the path to the stated strategic objectives and to provide a higher level of security even through reduced profitability. Thus, the economic security strategy of the business entity is oriented primarily to the external environment of existence (Carr, M. (2016), Sulphey, M. M., \& Alkahtani, N. (2017)).

\section{Methods}

It is worth noting that the way of building of an economic security strategy of the business entity is vectors for the movement and the adoption of managerial decisions for the achievement of the goal. To determine the basic security indicators it is necessary to outline the strategy of formation of an industrial organization security. In general, the economic security strategy of the business entity is a complex of most important management decisions, which are aimed at achievement of the desired level of protection of the existence of a particular enterprise.

Among the factors hampering entrepreneurs in achievement of the planned results and making productive use of 
their own competitive advantages, optimal implementation of their goals and prospects for further development one can distinguish the following ones:

underestimation by managers of all levels of tasks for the long-term perspective, narrowing of strategic vision, which requires a change in the external environment of the business entity;

an imbalance between the existing system of incentives for managers and other employees and key steps in implementation of the enterprise strategy; incomplete devotion and lack of commitment of performers;

lack of necessary resources for successful implementation of the main mission of the business entity;

undevelopment of a concrete, effective plan of measures for the implementation of a predefined strategy of the enterprise; relying on their own intuition and existing experience in making managerial decisions;

globalization tendencies that lead to significant changes in the internal and external plane of the functioning of the industrial enterprise substantially affect the buyers, criteria for the formation of consumer demand, production technological base, counteragents, specifics of the market space, capacity of the enterprise, entrepreneurial activity, etc.

\section{Results}

The formation of optimal strategy of economic security of the business entity is based on a systematic analysis of all production and economic activity for a certain period of time and the development of a set of measures that can ensure stability in the future in the operations of the business entity, as well as form the basis for its progress.

Factors that determine the proper state of the economic security strategy of the business entity are quite diverse and specific to each area of activity. However, it is possible to identify the typical factors that affect the appropriate state of the strategic security of the business entity, regardless of ownership and manufacturing sector:

The general production factors, that is, those that directly affect the activities of the manufacturer. They usually include: location of the industrial enterprise; natural resources that are available for use and their particular location on a particular locality; terms of use and key quality indicators; the availability of labour force and the level of education and skills of personnel; formed industrial and economic infrastructure and possible volumes of its exploitation; socio-economic conditions of life of the population.

A constant demand for a product is a factor that is important for the uniform balanced functioning of the organization. This factor applies to: long-term contracts on sales of products to potential buyers; competitive advantages of manufactured products; quality and guarantee obligations of the manufacturer; reasoned forecasts for demand in the market space for a particular product; the formation of a national and local order for manufactured products (Suter, M. (2016); Korauš, A.; Dobrovič, J.; Polák, J.; Kelemen, P. (2019)).

The variability of the external environment, which has an ambivalent character: on the one hand - it may be threats in the form of manifestation of the economic crisis, instability, etc., and, on the other hand, the emergence of innovative ideas and products arising from their implementation and guaranteeing the effective existence of the business entity, subject to the prompt use of such innovations (Biresselioglu, M. E., Yildirim, C., Demir, M. H., \& Tokcaer, S. (2017)).

The defining feature of the outer space at the present stage is its changeable ever-increasing state. By transforming the main Eshby cybernetic theorem for management needs, one can state that for the prompt response of enterprise managers, or more precisely to make timely and optimal managerial decisions, the timeliness of responding to threats in the external environment should be consistent with its degree of variability (Duffield, 
M. (2017), Emmers, R., \& Caballero-Anthony, M. (2017)). That is why, it is important for business entity not only its ability to take into account the factors that are present at the moment (as a rule, negative ones), but also take into account that in the future they can be modified or change their forms of manifestation and the level of influence. The timing of the occurrence of a probable negative event (usually associated with some indicator) and the ability of the industrial enterprise managers to predict the onset of such an event are equally important (Zhou, J., Wang, C., Li, Y., Wang, P., Li, C., Lu, P., \& Mo, L. (2017)).

Stability of suppliers of basic raw materials and basic materials. For this purpose, long-term contracts should be concluded for the supply of the necessary raw materials and materials, taking into account such criteria as deadlines and quality. It is also advisable to take into account the potential capabilities of major suppliers by diversifying supplies. As a rule, it is necessary to deal with several suppliers of raw materials and materials (3-4 or more) for the elastic pricing policy.

The presence of external competition on export products, which should: to comply with world standards; be competitive in quality and warranty service; be promising; have competitive advantages over imported products in the country, which will provide support to the domestic manufacturer (Dalevska, N.; Khobta, V.; Kwilinski, A.; Kravchenko, S. (2019)).

The existence of a competitive field encourages business entities to find effective ways of development that can ensure their success and demand for their products. However, existing competition theories are related to the current market environment, but they are not able to meet the needs of the future. This is their main flaw. The fiscal regulation of the business entity's operation involves: The formation of the security of the domestic manufacturer despite the form of ownership of the means of production; co-ordination of state policy in the field of taxation; creation of favourable conditions for manufacturers, taking into account the specific aspects inherent in a certain territory; protection in the manufacturing of products belonging to the group of critical imports; the formation of a state order for those groups of products financed from the budget and, accordingly, reduction of import for similar products.

High level of protection of information containing commercial secrets. The state is tasked with preserving the secrets of scientific and technological achievements, innovative technologies, intellectual property, "knowhow", as well as commercial secrets. The professionalism of managers of a business entity. The most important factors that can form an appropriate level of economic security for a business entity are the professional competence of senior managers and the entire team of managers (highly skilled personnel, an effective system of recruitment and training, ensuring the proper conditions of production and socio-economic support of personnel).

There are other factors of the strategy of economic security of the business entity, which are not directly related to the production and economic activity, but to a large extent affect the general state of production. Usually, they relate to the behavior of individuals, their morality or spirituality (theft, fraud, misleading). All of these factors should be considered taking into account the existing regulatory framework and directing them to achieve the production strategic goal, providing the appropriate level of strategic security for each individual manufacturer (MacLean, G. A. (2016)).

An appropriate strategy for economic security is provided through the implementation of a coherent policy, a set of approved actions that meet potential internal and external hazards. This policy will only be effective if the strategy and well-chosen tactics of security formation are clearly defined. It should be taken into account that the strategy of building economic security is based on polyaspectancy of forecasts of further socio-economic progress of the enterprise and changed according to the course of events in a certain way. The benefits of a poly-dimensional strategy are determined by the possibility of choosing among several alternatives (Arribas, I.; Espinós-Vañó, M. D.; García, F.; Tamosiuniene, R. (2019)).

At the same time, the long-term strategy of economic security of the business entity should also take into 
account additional aspects that ensure internal and external economic security: Uninterrupted power supply. Usually, in order to ensure a reliable operation of the business entity, it is expedient to use two alternative sources of electricity. At very important productions, it is necessary to take care of energy independence, having created a reserve source of kinetic energy (diesel power plant). Auxiliary heat and steam supply, in the case when the industrial organization uses a municipal combined heat and power production plant. Water supply for all needs of the organization. The presence of its own source, and in the case of using a municipal water supply - a sufficient reserve of water. The creation of the insurance stock of the necessary material, raw and technical resources at the enterprise for the stable operation of the business entity under unforeseen circumstances. Reliability of consumers of products of the business entity in payment for the received products. Uninterrupted operation of transport for timely supply of material resources and products to customers.

A system of measures aimed at preservation of resources and inventory and warehouses, as well as effective organization of protection in general. To do this, it is necessary to create and implement certain steps for internal and external information, and means of signalization.

The program can also include other necessary measures, taking into account the profile of the enterprise. The corresponding long-term program of strategic development of the economic security of the business entity formed must be approved usually by the management of the enterprise after proper discussion and approval, after which it will become mandatory for execution by all employees.

A well-grounded strategic program is designed to promote stability in the work of the business entity and provide an appropriate level of economic security. So, a program designed for a long period must be provided with the necessary financial and material resources. Typically, the control functions for the timely and complete implementation of the program is imposed on the manager of the senior management.

Traditionally, the following forms of the strategy of economic security of the subject of management are distinguished: those aimed at neutralization of existing and prevention of the emergence of potential hazards; those aimed at minimization of the occurrence of threats (possible or existing) to security; those intended to cover the damage caused; those concentrated on overcoming existing strategic imbalances in the process of creation of an innovative foundation for further development.

In the process of implementation of the economic security strategy, the progressive stages of improvement of the situation in the industrial organization are:

formation of new production and organizational structures; leasing application;

direct participation in events of international level (exhibitions, symposiums, seminars) and implementation of world achievements in the field of scientific and practical experience;

optimization of existing systems of calculations; increase in output;

accumulation of investments in the sphere of resource conservation;

proper motivation of the "resource" vector of study and design works;

introduction of the principle of critical lending terms; construction of a data processing center for payables and receivables;

establishment of a certain structural subdivision in the data processing center with the involvement of highly qualified specialists for tracking the process of accrual and payment of the required taxes and fees;

increase of wages to corresponding indicators of the leading countries; assignment of managerial functions to employees of the enterprise;

systematic improvement of the qualification level of employees; motivation of the management of the business entity to hire unemployed persons; improvement of socio-economic infrastructure of the subject of entrepreneurial activity; increase of the responsibility of employees, primarily in material form, for the results obtained. 
Therefore, the creation of a strategic security of an economic entity should consist of the following stages: use of appropriate effective production factors (new equipment, labour resources of the appropriate qualification, etc.); production of marketable products oriented to market demands, improvement of qualitative characteristics and appearance; establishing close ties with those suppliers of materials, energy resources and raw materials of good repute; adequate protection of commercial secrets of the enterprise; change, if necessary, the heads of the enterprise and its structural divisions.

To successfully implement measures to formulate the economic security strategy, it is necessary to outline the volume of necessary resources and attract both internal and external sources of financing (sale of a certain part of the property, active sale of available products, attraction of credit funds, etc.).

The development of a strategy for ensuring economic security of an economic entity should be based on key principles, in particular the definition of initial provisions for its content, structure and purpose.

Taking into account these principles will allow to form a common basis and unified approaches in order to create an appropriate strategy and a holistic approach to the issues of the security of an industrial enterprise.

The current management theory over the past few decades has overcome the rather difficult way of testing, in which various approaches and concepts emerged and disappeared as a result of the transformation of perception of the essence and importance of management for the development of each industrial enterprise, in particular, of the human community as a whole. According to well-known experts, the most important in management is the existence of a strategic vision of the manager.

This strategic vision includes:

the perception of managerial subordination and the logic of determinationn of the priority areas in response to the question: to what we are heading and in what way we need to achieve this;

the focus on distinguishing and responding to a changing environment that opens the potential and probable hazards;

a successful combination of forms and mechanisms of obtaining and ways of using investment resources; the attraction of highly skilled personnel to the production and introduction of ideas on the long-term development of the business entity and overcoming existing problems;

coordination of functional and production, strategic and current, analytical, planning and executive vectors of the business entity;

understanding of the potential and scope of the impact on creation of a supportive environment, not being limited to responding to challenges;

the focus on managing the processes of socio-economic progress of the business entity for the long-term perspective of creation of an optimal system of strategic management implemented using motivation to initiative and leadership instead of protection and banal imitation.

The strategic imperatives are used for the productive introduction of a business strategy of an entity. The harmonious approach to the substantiation of strategic imperatives is aimed at introduction of actual and fundamental imperatives for a particular sphere or a certain manufacturer.

The market value of an industrial enterprise depends on many factors that differ significantly in different fields. Therefore, when building a business strategy of an industrial organization it is expedient to distinguish factors such as: desirable geographic coverage, strong brand, financial and economic stability, proper quality indicators of products, the possibilities of intra-firm management in solving business interests at all levels, and the effective use of capital. On the basis of these factors, it is possible to identify the relevant strategic imperatives, which are the most important when creating an effective business strategy in an industrial organization, since they enable the desired level of formation of value.

The imperatives were grouped by function and are arranged in such a way that they are coordinated vertically and horizontally (Table 1). 
Table 1. Strategic imperatives for an industrial organization

\begin{tabular}{|c|c|c|c|}
\hline $\begin{array}{c}\text { Specification of the conditions } \\
\text { for the implementation } \\
\text { of imperatives }\end{array}$ & Generally supporting imperatives & $\begin{array}{c}\text { Imperatives } \\
\text { of development }\end{array}$ & $\begin{array}{c}\text { Purposeful } \\
\text { imperatives }\end{array}$ \\
\hline Analysis of own funds & Business processes & $\begin{array}{c}\text { Establishing the consumer } \\
\text { value of the goods }\end{array}$ & $\begin{array}{c}\text { Harmonization of relations } \\
\text { with contractors }\end{array}$ \\
\hline $\begin{array}{c}\text { Study of changes } \\
\text { in the external environment }\end{array}$ & Attraction of counterparties & $\begin{array}{c}\text { Development of } \\
\text { innovations }\end{array}$ & Focusing on target buyers \\
\hline $\begin{array}{c}\text { Study of changes } \\
\text { in the internal environment }\end{array}$ & $\begin{array}{c}\text { Balance of operational } \\
\text { and strategic goals }\end{array}$ & Brand offer & $\begin{array}{c}\text { Focusing on satisfying the } \\
\text { needs of the buyer }\end{array}$ \\
\hline $\begin{array}{c}\text { Diagnostics of the capabilities } \\
\text { of an industrial enterprise }\end{array}$ & $\begin{array}{c}\text { Presence of modern } \\
\text { communications }\end{array}$ & Balance of urgent needs and \\
opportunities
\end{tabular}

The main preconditions for the implementation of each individual strategic imperative are monitoring of changes in the organization's external environment, the availability of certain unique assets and operational analysis of the activity.

The managers of successful organizations rely, as a rule, on a strategic vision that is based on an analysis of customer inquiries, prospects and dangers, a competitive environment, perceiving such work as a routine activity, as well as studying and generalization of the internal environment of an industrial organization. The strategic vision is based on understanding by the managers in the first place and the whole team of personal responsibility for the possibility of long-term existence and comprehensive development of the subject of entrepreneurial activity, need for adequate management of the process and continuous support of the main types of production and economic activity to form and strengthen the competitive advantages, achieve high financial and economic indicators for a long time interval.

For the business entity, it is essential to realize that any strategic activity should focus on choosing such ways of life that can guarantee the optimum result in the future, taking into account the risk minimization. On the other hand, the organization is able to create an adequate level of protection against the probable threat.

Affirming the effectiveness of entrepreneurial activities in a strategic context, it is advisable to take into account strategic security at the same time.

So, if the emergence of strategic planning is the result of a dynamic external space, then the strategy of economic security becomes important in view of the deepening of crisis phenomena. In this regard, the strategic objectives of the entity and its strategy of economic security are closely interrelated.

The strategy of economic security of an industrial enterprise is aimed at creation of favorable conditions for productive work and an incentive to achieve the goal of entrepreneurial activity in a competitive environment in the presence of various risks through the operational detection and minimization of the impact of existing threats. At the same time, due attention to the state of the economic security strategy is the formation of a certain set of key indicators that confirm the safe state of the environment of the entity's existence at a certain time of the onset of the predicted negative (positive) phenomenon.

An analysis of the activity of organizations allows to distinguish the characteristic features of business strategy development:

focusing on innovative opportunities for increase the efficiency of work that appear on the market in order to further capitalize on the product, that is, finding the imperatives to reduce the gap between financing the desired direction of enterprise development and relevant competences (in particular, growth, takeover, creation of alliances, etc.);

finding acceptable alternatives for consumer expediency as a method of elimination of direct hard competition; the application of approaches that will increase the profitability of an enterprise in obtaining value added;

the introduction of strategic control imperatives that will allow to increase efficiency for some time. 
The justification of the imperatives required for an industrial enterprise is aimed at introduction of a certain positioning of long-term principles that should be implemented in order to achieve the desired performance of the business entity. In the process of strategic planning, analysis and implementation, all this will help to effectively organize the sharing of relevant resources by prioritizing efforts and time.

Since the competitive field lies in the struggle for time, resources and capital, then the systematization of strategic imperatives will allow to justify and select the most successful decisions that will allow to achieve the objectives of the business entity in the best way.

\section{Discussion}

When forming imperatives it is advisable to take into account the following factors of economic security: the timeliness and appropriateness of certain institutional changes with the achievement of economic security, the current state of the institutional environment, need in periodical publishing of the priority of responding to various economic threats, public opinion, effectiveness of coercive and operational mechanisms, effectiveness of solving existing and potential problems of introduction of new norms and institutions, overall level of transformation and transaction costs in implementation of institutional changes, need to focus on the dialectical factors of objects and subjects of the system, corresponding division of levels of relationships that reflect the relevant features of relations arising in the process of achievement of economic security.

The external environment, which affects the general level of economic security of the business entity is characterized by indicators of liquidity, ability to fulfill obligations on loans, solvency and competitiveness, which are in close interaction. Formation of security in the area of achievement of the creditworthiness of an industrial organization can only take place if the manufacturer has sufficient funds, fixed assets and current assets of the corresponding volume, liquid assets, which are necessary for the fulfillment of obligations assumed by them on the basis of loan agreements.

The main external indicators of determination of the overall level of economic security of an industrial organization is the presence of strong competitive advantages. If the business entity is able to achieve a high competitive level, that is, to maintain its position in a severe competition with the production and sale of finished products, then its strengths (advantages) can become a solid core of long-term security in the group of companies producing identical products and compete on the external and internal market and, thus, will provide the organization with economic success in the future.

Given the need for systematic monitoring of the current state and prospects of organizations in the analysis of the effectiveness of use of their resources and in other cases, it is expedient to be based on potential capabilities. That is, it is advisable to pay attention to the formation of the corresponding potential of organizations, since in today's economic conditions, issues of rational use of available resources are especially relevant. The formation of competitive advantages depends on the quality of implementation of the enterprise's potential.

For the effective functioning of organizations, it is necessary to develop qualitatively social, labour, material and technical and other elements of the potential. Therefore, the exclusive attention of enterprise managers should be given to the determination and rational use of existing and potential socio-economic capabilities. A significant obstacle in identification of existing and potential capabilities for improvement of the efficiency of activities is the traditional way of using resources, which does not always meet the current market requirements.

It is also possible to increase social potential through mobilization of unused labour reserves. Thus, the application of efforts to eliminate the high level of downtime, occupational morbidity of workers, non-compliance of the average level of education and qualifications of employees with normative indicators can contribute to increase of the social potential of organizations. The most significant impact on the social potential of organizations is the level of education and qualifications of workers, working conditions and living conditions of employees, personnel and social policy of the organization. 


\section{Conclusions}

So, the main thesis of the concept of strategic management at the present stage is: a corporate (general) strategy that should set only the vectors of the business entity's progress and outline the general purpose of the strategic direction, while clarifying the steps to achieve the business goal in different areas is implemented through the development and introduction of functional strategies, in particular, innovative, marketing, financial and economic, staffing, etc. The strategy of the business entity security is the first in this list.

Based on the foregoing, the strategy of economic security as a certain component of lobbying and the elaboration of a complex of strategic tasks is a favourable ground for general plans of expansion and deepening of the manufacturer's own strategically important advantages in a competitive environment.

The development of an effective system of the economic security strategy of an industrial enterprise and ensuring its proper existence must be based on the methodological basis of the theory of security. It is important to correctly outline the goal of the business entity's security, set of tasks for the successful implementation of a specific goal, key functions of the established industrial enterprise security system, that is, it is necessary to clearly define the scope of the operation of the specified system.

The formation of optimal strategy of economic security of the business entity is based on a systematic analysis of all production and economic activity for a certain period of time and the development of a set of measures that can ensure stability in the future in the operations of the business entity, as well as form the basis for its progress.

The reasons for introduction of a controlling subsystem in the practice of domestic enterprises are: increase of instability of the environment; complication of the enterprise management system, which requires coordination mechanisms within the system; the need to build a system of information support of management.

Controlling is an important tool for successful operation of an enterprise, because: it provides management and owner of the organization with information for making managerial decisions, managing resources by integrating the processes of collection, processing, preparation, analyzing, and interpretation of information; provides enterprise survival at tactical and strategic management levels; contributes to the optimization of the dependence of "revenue-expenditure-profit".

\section{References}

Arribas, I.; Espinós-Vañó, M. D.; García, F.; Tamosiuniene, R. (2019). Negative screening and sustainable portfolio diversification, Entrepreneurship and Sustainability Issues 6(4): 1566-1586. https://doi.org/10.9770/jesi.2019.6.4(2)

Biresselioglu, M. E., Yildirim, C., Demir, M. H., \& Tokcaer, S. (2017). Establishing an energy security framework for a fast-growing economy: Industry perspectives from Turkey. Energy research \& social science, 27, 151-162. https://doi.org/10.1016/j.erss.2017.03.007

Carr, M. (2016). Public-private partnerships in national cyber-security strategies. International Affairs, 92(1), 43-62. https://doi. org/10.1111/1468-2346.12504

Ciobanu A., Androniceanu A. (2018). Integrated human resources activities - the solution for performance improvement in Romanian public sector institutions, Management Research and Practice, 10(3), 60-79.

Dalevska, N.; Khobta, V.; Kwilinski, A.; Kravchenko, S. (2019). A model for estimating social and economic indicators of sustainable development, Entrepreneurship and Sustainability Issues 6(4): 1839-1860. http://doi.org/10.9770/jesi.2019.6.4(21)

Dobrovolskienė, N.; Tvaronavičienè, M.; Tamošiūnienė, R. (2017). Tackling projects on sustainability: a Lithuanian case study, Entrepreneurship and Sustainability Issues 4(4): 477-488. http://doi.org/10.9770/jesi.2017.4.4(6)

Drobyazko, S. (2018). Accounting management of enterprises' own of in the conditions of legislative changes. Economics and Finance, 10,4-11. URL: http://ecofin.at.ua/maket_ehkonomika_i_finansy_06_2018.pdf

Drobyazko, S. (2018). Features of tourism services accounting structuring in the information-oriented society. Economics and Finance, Volume, 6, 44-49. URL: http://ecofin.at.ua/maket_ehkonomika_i_finansy_10_2018.pdf 
Dueri, S., Guillotreau, P., Jiménez-Toribio, R., Oliveros-Ramos, R., Bopp, L., \& Maury, O. (2016). Food security or economic profitability? Projecting the effects of climate and socioeconomic changes on global skipjack tuna fisheries under three management strategies. Global environmental change, 41, 1-12. https://doi.org/10.1016/j.gloenvcha.2016.08.003

Duffield, M. (2017). War as a network enterprise: the new security terrain and its implications. In The Criminology of War (pp. 109-121). Routledge. URL: https://www.taylorfrancis.com/books/9781315086859/chapters/10.4324\%2F9781315086859-6

Emmers, R., \& Caballero-Anthony, M. (2017). Understanding the dynamics of securitizing non-traditional security. In NonTraditional Security in Asia (pp. 13-24). Routledge. URL: https://www.taylorfrancis.com/books/e/9781351914369/chapters/10.4324\% 2F9781315247878-9

Havierniková, K.; Kordoš, M. (2019). Selected risks perceived by SMEs related to sustainable entrepreneurship in case of engagement into cluster cooperation, Entrepreneurship and Sustainability Issues 6(4): 1680-1693. http://doi.org/10.9770/jesi.2019.6.4(9)

Hilorme, T., Nazarenko Inna, Okulicz-Kozaryn, W., Getman, O. \& Drobyazko, S. (2018). Innovative model of economic behavior of agents in the sphere of energy conservation. Academy of Entrepreneurship Journal, Volume 24, Issue 3, 2018. URL: https://www. abacademies.org/journals/month-september-year-2018-vol-24-issue-3-journal-aej-past-issue.html

Korauš, A.; Dobrovič, J.; Polák, J.; Kelemen, P. (2019). Security position and detection of unusual business operations from science and research perspective, Entrepreneurship and Sustainability Issues 6(3):1070-1079. http://doi.org/10.9770/jesi.2019.6.3(15)

MacLean, G. A. (2016). Human security in the national interest? Canada, POGG and the 'New'Multilateralism. In A Decade of Human Security (pp. 79-88). Routledge. URL: https://www.taylorfrancis.com/books/e/9781317188445/chapters/10.4324\%2F9781315564630-12

Monni, S.; Palumbo, Tvaronavičienė, M. (2017). Cluster performance: an attempt to evaluate the Lithuanian case, Entrepreneurship and Sustainability Issues 5(1): 43-57. http://doi.org/10.9770/jesi.2017.5.1(4)

Sulphey, M. M., \& Alkahtani, N. (2017). Economic security and sustainability through social entrepreneurship: the current Saudi scenario. Journal of Security and Sustainability Issues, 6(3). URL: https://papers.ssrn.com/sol3/papers.cfm?abstract_id=3061091

Suter, M. (2016). Improving information security in companies: How to meet the need for threat information. In Power and Security in the Information Age (pp. 143-164). Routledge. URL: https://www.taylorfrancis.com/books/9781317076964/chapters/ 10.4324\%2F9781315601793-9

Tetiana, H., Karpenko, L., Fedoruk, O., Shevchenko, I., \& Drobyazko, S. (2018). Innovative methods of performance evaluation of energy efficiency project. Academy of Strategic Management Journal, 17(2), 112-110. URL: https://www.abacademies.org/articles/innovativemethods-of-performance-evaluation-of-energy-efficiency-projects-7067.html

Tvaronavičienė, M. (2018). Toward efficient policy making: forecasts of vulnerability to external global threats, Journal of Security and Sustainability Issues 7(3): 591-600. https://doi.org/10.9770/jssi.2018.7.3(18)

Von Gliszczynski, M., \& Leisering, L. (2016). Constructing new global models of social security: How international organizations defined the field of social cash transfers in the 2000s. Journal of Social Policy, 45(2), 325-343. https://doi.org/10.1017/S0047279415000720

Zhou, J., Wang, C., Li, Y., Wang, P., Li, C., Lu, P., \& Mo, L. (2017). A multi-objective multi-population ant colony optimization for economic emission dispatch considering power system security. Applied Mathematical Modelling, 45, 684-704. https://doi.org/10.1016/j. apm.2017.01.001 
Short biographical note about the contributors at the end of the article:

Yuri TSENKOV, Assistant Professor, UNWE - Sofia, Faculty "Infrastructure", Department "National and Regional Security" ORCID ID: https://orcid.org/0000-0001-5788-0668

Register for an ORCID ID:

https://orcid.org/register

This work is licensed under the Creative Commons Attribution International License (CC BY).

http://creativecommons.org/licenses/by/4.0/ 